\title{
HES4 wt Allele
}

National Cancer Institute

\section{Source}

National Cancer Institute. HES4 wt Allele. NCI Thesaurus. Code C104258.

Human HES4 wild-type allele is located in the vicinity of $1 \mathrm{p} 36.33$ and is approximately $1 \mathrm{~kb}$ in length. This allele, which encodes transcription factor HES-4 protein, is involved in the negative regulation of transcription. 